\title{
NOMADEJA JA AKTIIVISIA KANSALAISIA
}

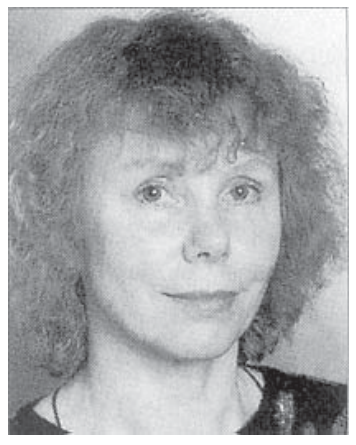

Anja Heikkinen ansallisvaltioiden ja kansalaisuuden itsestään selvät merkitykset
näyttävät olevan muuttumassa tavalla, joka muistuttaa niiden
aktiivisen tekemisen aikakausia. Aikuiskasvatuspolitiikka, -käytäntö ja -tutkimus ovat mukana muutoksessa: onko niissä kehitteillä kansalaisuuden uusi muunnos, joka yhdistää globaaleille markkinoille kelpaavan kuluttajatuottaja-työllistyjän ylikansallisesti toimivaan kulttuuriseen nomadiin?

Kansallisvaltio, jota halutaan sotilaallisesti, taloudellisesti ja poliittisesti puolustaa ja jonka uskotaan puolustavan asukkaitaan, tarvitsee kansan ja kansalaiset. Ne näyttävät puolestaan tarvitsevan edustuksen, näkyväksi tekemisen ja henkilöitymisen. Valtion, kansan ja kansalaisuuden suhteet ovat saaneet maailmassa monenlaisia muotoja. Ilkka Liikanen on tutkimuksissaan osoittanut fennomaanien pitkän ja esimerkillisen projektin itsensä, ajattelunsa ja toimintatapansa tekemiseksi suomalaisen kansan edustukseksi. Kansanliikkeiden ja järjestöjen tuli osaltaan tukea valtion ja kansalaisen suhteen välittömyyttä. Yhdysvaltoihin sopivaa kansalaisuutta taas muotoiltiin Putnamin mukaan yhteisöllisyyttä rakentavissa liikkeissä ja itsekasvatuksellisissa ohjelmissa, joiden murentuminen uhkaa kansallisvaltiollista yhteisyyttä. Kansallisvaltioiden rakentamisen vaihtoehdoille näyttää silti olleen yhteistä niihin kelpaavien kansalaisten systemaattisen ja massaluonteisen kasvattamisen institutionalisoiminen. Se käynnistyi yhtäältä lasten ja nuorten koulumaisesta kasvatuksesta, toisaalta alueellisesti tai sosiaalisesti rajattujen yhteisöjen elämäntapojen ja asenteiden muovaamisesta aatteellisen, poliittisen ja ammatillisen valistuksen kautta.

Akateeminen intelligentsia on perinteisesti pyrkinyt tai joutunut muotoilemaan sosiaalisen osallistumisen ja asemoitumisen käsitteellisiä ja ideologisia perusteita. Kansallisvaltioyhteiskuntien ja kansallisten talouksien rakentamiseen liittyi myös kasvatuksen ja sivistyksen tieteellisten käsitteiden ja mallien kehittäminen. Kun kansa ja sivistyneistö ovat tuottaneet toisiaan, on tulkinta sivistyksestä ollut keskeinen. Juha Siltala on kuvannut suomalaisen sivistyneistön sisäistä, psykohistoriallista itsensä muotoilun projektia, jossa se on etsinyt kansaa itsestään ja itseään kansasta. Sivistyneistön tulkintamahdollisuudet ovat riippuneet sen suhteesta kansallisiin poliittisiin ja taloudellisiin eliitteihin tai sellaisiksi pyrkiviin ryhmiin.

$\mathrm{P}$ erinteinen suomalainen aikuiskasvatus on määritellyt itsensä sivistyksen edustukseksi, sivistyneistön ja kansan itseymmärryksen mahdollistavaksi toimintakentäksi. Kuitenkin sen sivistyskäsitystä ovat hallinneet länsimaisen opillisen eliitin henkiset arvot ja usko tieteeseen ja tiedolliseen oppimiseen. Vaihtoehtoisiin tulkintoihin pyrkivät ohjelmat näyttävät sopeutu- 
neen dominoivaan sivistysdiskurssiin synnyttäen puhetta esimerkiksi teknillisestä ja ammatillisesta sivistyksestä tai vaikkapa sydämen sivistyksestä.

Aikuiskasvatuksen paraatipuolella sivistyneistön, taloudellisen ja poliittisen eliitin ylläpitämä itseymmärrys on edelleen voimissaan. Kansalliseen aikuisten koulutustason nostamisohjelmaan pyrkivät koulutusinstituutiot eivät epäröi sovittaa sosiaali- ja työvoimapoliittista alihankintatehtäväänsä vapaan sivistystyön kunniakkaisiin kansakunnan rakentamisen ja sivistymisen perinteisiin. Erityisesti Irakin sota on tuonut näkyviin talouden ja politiikan ylikansallistumiseen sisältyvän sotilaallisen ulottuvuuden. Kansalaisen uuden muunnoksen on haluttava puolustaa jotain kansallisvaltioon samaistumatonta entiteettiä ja uskottava sen puolustavan itseään. Sivistysdiskurssin muuntuminen, jopa korvautuminen, yhtäältä markkinataloudellisella oppimis- ja työllistymisdiskurssilla, toisaalta itserefleksiivisellä yksilödiskurssilla ilmentää myös sivistyneistön muuntumista. Millaista tiedollis-ideologista edustusta uudelle kansalaisuudelle se rakentaa uusissa sivistyksen tulkinnoissa ja millaisiin taloudellis-poliittisiin liittoutumiin sen on projektissaan nojauduttava? Zygmunt Bauman jatkaa teoksessaan Notkea moderni länsimaisten sosiologien ja postmodernien ajattelijoiden vuosia kestänyttä kertomusta kehkeytyvästä uuspaimentolaisuudesta kansalaisuuden ylittävänä maailmassa olemisen tapana. Millaista aikuiskasvatuksen itseymmärrystä oikeuttaa paikkaan ja aikaan sitoutumattoman, toiseen ja vieraaseen alati uteliaan avoimesti ja vastavuoroisesti suhtautuvan intellektuellin esikuva?

ässä Aikuiskasvatus-lehden teemanumerossa herätellään keskustelua
kansan ja kansalaisuuden vanhoista ja uusista muunnoksista. Samalla
kokeillaan sisällön uutta jäsennystä, joka toivottavasti viestii lukijoille ja kirjoittajille toimituskunnan pyrkimyksiä lehden kehittämiseksi keskustelevampaan suuntaan. Kaikkien numeroiden rungoksi odotamme aikuiskasvatustutkimusta ilmentäviä tieteellisiä artikkeleita, aikuiskasvatuksen käytännöistä nousevia ja ajankohtaisia poliittisia kysymyksiä käsitteleviä kirjoituksia sekä teoriaa, käytäntöjä ja politiikkaa kommentoivaa keskustelua ja puheenvuoroja. Myös kirja-arviointien toivomme edustavan monipuolisesti teoriaa, politiikkaa ja käytäntöjä. 